\title{
Fulfilling the promise of the Earth Charter
}

The purpose of this book is to stimulate dialogue and action on global ethics and its role in the governance of individual societies and the international order. Such inquiry is imperative, given the extraordinary global challenges that face us today.

By 'global ethics', we mean the ethical principles and virtues that enable us to share and care for Earth and one another. Over the course of the last two centuries, the discussion of global ethics has been increasingly organized around a constellation of transformative ethical purposes deemed essential for sustaining a dignified human life and a flourishing planet. These purposes are variously stated; but in one form or another, they typically include justice (inclusive of respect for universal human rights); the organic wellbeing of the human species and the ecological integrity of the planet; obligations to future generations; peaceful, non-violent relations between individuals and communities the world over; liberal constitutional democracy and the rule of law. Each of these constitutes a fundamental ethical domain of considerable complexity. How to bring them together in mutually supportive relationships - in principle and in practice - is the core issue of debate in global ethics. The ultimate aim is a credible and persuasive normative framework for governing human civilization under contemporary geopolitical, cultural and biospheric conditions.

The platform for our discussion is the Earth Charter, an international civil society declaration launched in 2000 by the Earth Charter Council and Green Cross International. The question of the future of the Earth Charter provides a focus similar to that which the Universal Declaration of Human Rights often serves for wide-ranging inquiry, debate and transformative action on global values that reaches well beyond the document itself.

At the time of the launch of the Earth Charter in 2000, there was hope that the new millennium would usher in a new era of international cooperation and governance founded on consensus on leading global ethics values. The four parts of the Earth Charter text are organized around these values and unified by the comprehensive imperative to 'respect and care for the community of life'. Principle 1.3, 'Build democratic societies that are just, participatory, sustainable, and peaceful', and Principle 1.4, 'Secure Earth's bounty and beauty for present and future generations', are examples of how the values identified 
above are interwoven throughout. There was hope that by mobilizing a significant portion of the planet's societies and traditions on behalf of the 'great work' of cultural reconstruction global ethics requires, by repenting of its transgressions and redesigning our ways of inhabiting the planet, humankind could make the sacrifices and changes in its way of life that the ethical demand for a just, sustainable and peaceful sharing of the Earth requires.

\section{THE CRISIS IN GLOBAL ETHICS AND THE FUTURE OF THE EARTH CHARTER}

What has happened instead is that the world has largely regressed in regard to each of these values, with inequalities in wealth and power within and between nations reaching unprecedented levels; widespread violations of human rights and racial, religious and ethnic discrimination; continuing poverty and rising food insecurity; accelerating atmospheric and oceanic warming, species extinction and biological annihilation; terrorism, civil wars and military invasions; rising investments in military preparedness and a retreat from nuclear arms control treaties; and - perhaps most devastating for hopes for ethically driven international cooperation and law - the erosion of democratic norms and the rise of populist authoritarian governments in many nations across the world. New issues in global ethics - such as the migration of large numbers of refugees, government and corporate surveillance, genetic engineering and artificial intelligence - have emerged; while issues such as unsustainable population growth and the reform of the United Nations have fallen from the agenda. In spite of ambitious international efforts, such as the 2015 United Nations Sustainable Development Goals, to integrate the leading global ethical ideals, longstanding conflicts between advocates for social justice and advocates for ecological integrity continue, and issues of peace and security are poorly addressed. In some quarters, the authority of modern science itself is under attack.

We should not underestimate the progress that has been made on some issues, such as gender equality, or the increase in global literacy. Or fail to note the explosion of academic studies, film documentaries and news coverage that has revealed the unsustainable, unjust and violent realities of human history and the revolutionary and reformist movements that have struggled to correct them. Or the tide of literature, art and other creative expression devoted implicitly or explicitly to advancing global ethics values. Or the innovative grassroots, civil society, business and state initiatives that are taking action on climate change.

Nonetheless, dystopian visions dominate the public imagination and the outlook for the planet as a whole is bleak. Liberal democratic belief in the 
capacity of human beings to exercise scientifically informed and ethically principled self-government is severely in doubt.

In order to make sense of our situation, we must recognize that the watershed for contemporary global ethics was the western Enlightenment and the capitalist-led industrial revolution that followed. Together they bequeathed the major premise underlying the pursuit of global ethics in the following two centuries: that 'progress' in mastering nature and raising the material standards of life for the masses by technological innovation and profit-driven growth in economic production and consumption is the engine for achieving a cosmopolitan world civilization. This, in a word, has been the faith of the modern age and the promise of 'globalization'. It has always been challenged by dissenters, but it is a protean idea and has held firm through the ravages of revolutions, depressions and wars. Indeed, it was reaffirmed with ever more determined zeal in what has been called the 'Great Acceleration' of the post-Second World War years.

All this changed in the opening decades of the twenty-first century. It was as though the nations of the world, making a sober assessment of the needs and desires of their growing populations and the policies necessary to secure the sustainability of the planet, suddenly realized there was simply not world enough for sharing if the modernization plans of each nation were to be realized.

The withdrawal from even the pretence of sharing the planet has been most notable in the case of the United States which, in spite of its many hypocrisies and crimes, has seen itself, and often been viewed, as the 'indispensable nation' if a regime of ethically enlightened international law is to prevail.

Sudden awareness of the illusions of the faith of modernization has not diminished most citizens' attachment to its material benefits. It is not surprising under these circumstances that the discussion of global ethics has become muted or circumscribed, and those civil society associations that continue to promote them often refer to themselves as members of the 'resistance'.

This reversal of hopes and fortunes has come as a shock to the global ethics movement. The irony, however, is obvious. One reason for the shock is that it is now apparent that the global ethics movement in its predominant intellectual and political expressions has ridden on the rails of the same basic modern worldview. It has marginalized those voices that have insisted on 'limits' to economic and population growth, called for substantial redistribution of wealth or questioned the notion that American military and economic dominance of the planet is good for all humanity. In numerous international accords 'development' was qualified by 'just', 'sustainable', 'peaceful' and 'democratic', but it was still modern development. The Stockholm Declaration firmly states: 'The capability of man to improve the environment increases with each passing day.' 
Yet the Earth is simply not amenable to top-down command and control management, however appealing the images of 'nature as a garden' advanced by eco-modernists. The planet cannot be governed by coalitions of its most powerful ruling elites because they are simply not in control, however successful they may be in repressing resistance.

The stakes are high. We can no longer assume there is room on the planet for some to go one way and others to go in the opposite direction. As the Earth Charter affirms, 'we are one human family and one Earth community with a common destiny', and our choices between just and unjust, sustainable or unsustainable, have global impact. We no longer live in the Holocene, where humans had the luxury of separating their idealistic ambitions for a shared life from the institutions of governance, or 'humanity' from 'nature' conceived as an objectified external 'other'. We now live in the hourglass of the Anthropocene.

For far too long, the liberal international community has assumed that because cooperative actions by the nations of the world are necessary if there is to be any hope for a just, sustainable and peaceful future for the planet, they will therefore inevitably follow. By advocating such actions, we are on the side of history. Recent events have amply demonstrated that there is nothing inevitable about human cooperation, even for collective planetary survival. It is as likely - perhaps even more likely - that in the face of climate change, food shortages and population pressures, those nations that are able will do everything within their power to close their borders, adapt to the new climatic regime and repress actions by other nations to expand their exploitation of energy and other natural resources.

Only on the assumption of a profound covenantal loyalty to the Earth and one another, as Engel argues here, and the assumption of the ethical responsibilities that are required to fulfil that covenant, will the actions that are necessary become deeds performed. Reasoned, ethically justified and politically legitimated planetary self-government has an unprecedented urgency and ultimacy. Human beings will prove themselves to be the 'moral species' or they will not.

\section{RENEWING THE GLOBAL ETHICS DIALOGUE AND FOUNDING A NEW GLOBAL POLIS}

Can a renewal of dialogue on global ethics inspire an international political movement that can reclaim the high moral ground, disenthrall itself from the chimera of utopian modernization and motivate a vision of just, sustainable and peaceful sharing of the beauty and abundance of life with sufficient power to generate new forms of citizenship and new institutions of local, national and international governance that serve the common good? 
What role can 'declarations' such as the Earth Charter that seek consensus among citizens on fundamental ethical values play in enabling dialogue and moral renewal? As the Earth Charter concludes: 'We must deepen and expand the global dialogue that generated the Earth Charter, for we have much to learn from the ongoing collaborative search for truth and wisdom.'

The heart and soul of global ethics is the conversation in which it consists. This is why questions regarding who is invited to participate, on what terms, with what agenda and to what ends are always themselves matters of debate.

Over the course of his career, J. Ronald Engel has sought with his colleagues to create the conditions for dialogues on global ethics that are (1) inclusive in membership; (2) conceptually and empirically rigorous; (3) free, equal and mutually respectful; (4) enduring, constituting an extended inquiry; (5) focused on achieving prescriptions for action in the world; and, perhaps most distinctively, (6) embedded in institutions whose members have the predisposition and power to act on these prescriptions. Scientific, philosophical and other theoretical contributions are critical; but global ethics dialogue is primarily a matter of practical reason, an exemplary exercise in personal and collective moral self-government.

The pioneering volume of essays that Ron Engel compiled and published with Joan Engel, 'Ethics of Environment and Development: Global Challenge, International Response' (Pinter Publishers, 1990; University of Arizona Press, 1991), was one of the fruits of the international dialogue that he initiated and led for many years through the World Conservation Union Ethics Working Group, and serves as a model for the kind of cross-cultural and inter-disciplinary dialogue which is urgently needed today. ${ }^{1}$

Calls for a renewal of dialogue on global ethics and the future of the Earth Charter and comparable international ethical declarations have come from a number of quarters in recent years.

'The Earth Charter in Action: Toward a Sustainable World', edited by Peter Blaze Corcoran, Mirian Vilela and Alide Roerink (KIT Publishers, 2005), is a stimulating example of the kind of dialogue that is needed if we are to understand the importance of the Earth Charter today. 'The Earth Charter: A Framework for Global Governance', edited by Klaus Boselmann and J. Ronald Engel (KIT Publishers, 2010), laid foundations for the inquiry on how the Earth Charter might serve as a model constitution for the world. In 2017 the Earth Charter Initiative (ECI) circulated a paper by Brendan Mackey, 'A Reflection on The Earth Charter Project and its Mission in the

Engel's many other publications on the theory and practice of global ethics may be accessed at www.meadville.edu/library-and-archives/john-ronald-engel/. 
Anthropocene', ${ }^{2}$ which included a proposal 'to review and update the Earth Charter in light of issues arising since the Earth Charter was launched in the year 2000'. Responses by members of the Earth Charter network were published on the ECI website, including 'Giving the Earth Charter a New and More Powerful Voice’ by Klaus Bosselmann, Ron Engel and Prue Taylor. The Great Transition Initiative led by Paul Raskin; the Yale Forum on Religion and Ecology led by Mary Evelyn Tucker and John Grim; and the World Social Forum, among others, seek to stimulate international dialogue on global ethics and often cite the Earth Charter as an important reference point.

The dialogue that follows began with two recent calls by Engel for vigorous ethical debate and covenanted action in light of the unfulfilled promise of the Earth Charter.

The first of these, 'Summons to a new axial age', came as a result of his participation in the 2012 World Conservation Congress in Jeju, South Korea, where he observed first hand the courage of the citizens of Gangjeong Village in fighting for the survival of their indigenous community and its rare natural environment in the face of plans by the government of South Korea to replace their settlement and harbour with a deep water naval base. The vote by an overwhelming number of government and non-governmental organization members of the World Conservation Union at its Congress in 2004 to make the Earth Charter 'the guide to IUCN policy and programme' was one of the most significant actions on behalf of the Charter in the opening years of the twenty-first century. Eight years later, in Jeju, however, not only was there no inclination to submit South Korea's much touted programme of 'green growth' to ethical critique, but everything possible was done to keep the issue of Gangjeong Village from reaching the attention of delegates. This contradiction between espoused principles and actual behaviour led to the chapter that begins our book. Engel argues that the global ethics movement gathered around the Earth Charter must have the courage to stand by the ontological and empirical truth upon which the Charter is founded - that we are living in a relational universe - and the moral truth that we have the obligation to 'respect and care for the community of life' in all its diverse manifestations. This requires that we name the agencies responsible for the devastation of the commons and mobilize the political power to halt the scorched-earth policies of globalization.

2 See http://earthcharter.org/wp-content/uploads/2018/02/Mackey-Brendan-20-ye ars-on-V_FINAL-18July17-3-small-things.pdf. 
Engel concludes by drawing upon Nigel Dower's principle of 'critical loyalty' to the Earth Charter vision and movement and proposing that the ECI:

convene a summit of leaders of the outstanding declarations of global ethics in current circulation for the purpose of reigniting the dialogue on global ethics and creating a global alliance with greater organizational power and influence than any can exercise independently.

He then fleshes out in detail a list of ten topics that should form the agenda for such a summit. They range from how to go about the task of 'degrowth' to spelling out the meaning of 'Earth Democracy'.

In his second call to a renewed global ethics dialogue, 'Can the Earth Charter movement be renewed?', Engel joins the many voices who have called for a 'new covenant with Earth' as a necessary step for humankind to take if it is to successfully make the great transition through the Anthropocene. The dominant trajectory of the modern global order is a betrayal of one another and the creative sources of our existence; and only the kind of commitment that acknowledges our unconditional obligations to the flourishing of life, which is inherently covenantal, will redeem us. When persons take vows of commitment to one another on behalf of a shared cause of ultimate worth and importance, they become willing to take serious risks on behalf of the cause they share. Engel holds that those who share the vision and principles of global ethics enunciated in the Earth Charter must become such a covenanted community if they are to have the capacity to ignite the truly inclusive global dialogue our situation demands and empower a new order of global governance. This chapter seeks to spell out what this would mean for the work and organization of the Earth Charter movement.

This volume is an edited collection of authors responding to Engel's invitations to renew dialogue on global ethics and the future of the Earth Charter. The authors come from the fields of law, philosophy and theology. Each is a significant figure in the creative development of global ethics and many were personally engaged in the drafting, launch and subsequent initiatives of the Earth Charter movement. Each is also a treasured colleague of Engel's and has participated in one or more of the many conversations he has helped convene over the course of his career. Prue Taylor, in her biographical chapter 'Keeping faith with life', gives us the personal and institutional background for many of these conversations.

Engel's colleagues join him in his call for a renewal of the dialogue that can bring the issues of global ethics and the promise of the Earth Charter to the forefront of the public mind. They draw not only upon the two chapters that are primarily under examination here, but also on other of his writings. A number join him in his argument that covenantal ethics offers a promising way to move 
ahead. They also do him the honour of critically interrogating his work and point to ways in which it is incomplete or in error. As a whole, the chapters in this book model the kind of rigorous intellectual debate and shared inquiry that need to occur in as many fora as possible today.

Taken together, the chapters suggest that a restructuring of the modern order of global governance is under way before our eyes. The destructive consequences of this restructuring are obvious and they are likely to grow worse. As Peter D. Burdon shows in his chapter, even if humans were to withdraw completely, a pristine Holocene will not return. We cannot escape tragic choices and immense responsibilities. Other countervailing movements, local and transnational, prefigure the potential that exists for something new in human history to arise, the emergence of a new global 'polis', in Engel's terms, a confederation of covenanted 'democratic ecological citizens' and communities. What are the thoughts and actions required by those faithful to the vision of the Earth Charter and committed to building a new polis on the values of global ethics in the midst of our current upheavals? This became the primary agenda of discussion by those who authored this book. 